\title{
STUDIES ON SILAGE IN PUERTO RICO. I. METHODS OF FNSILING AND RESULTING QUALITY OF MERKER, CANE TOPS AND PARA GRASS SILAGES
}

\author{
By L. Rivera Brenes, ${ }^{1}$ F. Marchán, ${ }^{2}$ and E. Del Toro. ${ }^{3}$ \\ INTRODUCTION
}

Recurrent deficiencies in both quantity and quality of forage crops and the use of large amounts of costly concentrate feeds are among the major factors responsible for high costs in milk production in Puerto. Rico. A wasteful use of forage is the inevitable result of the present method of forage cropping. In the areas where soilage forage is used, it is nearly impossible to feed grass at the optimum stage of maturity and at the same time avoid both shortage during the dry season and over-abundance during favorable growing periods. In pasture areas the problem is even more acute, requiring a large acreage for pasture and also the use of large quantities of concentrates during the dry-weather months in order to keep the cattle alive.

Furthermore, under present methods of forage cropping land is not economically used. Sufficient land must be set aside to provide minimal quantities of forage of any quality during. dry seasons. The economy of Puerto Rico will profit if these lands were freed to be put to a more intensive use.

Proper methods of storage are necessary to provide sufficient forage of good quality during the whole year. The making of hay is difficult due to frequent rains during the growing seasons and because the grasses now used are too thick-stemmed to dry and handle as hay, unless they are chopped and dried artificially. Because of the climate, the crops now grown, and the availability of inexpensive molasses, the preservation of grasses as silage offers a rational solution to the problem.

At present there are few silos in use in Puerto Rico. Information concerning the usefulness of presently grown crops, methods of making silage of these crops, and the economic value of silage in Puerto Rico is meager.

It was the purpose of this study to secure information concerning the possibility of making silage of grasses grown in

${ }^{1}$ Associate Animal Husbandman.

2 Assistant Chemist.

${ }^{3}$ Assistant Animal Husbandman. 
Puerto Rico, the best methods to be used, the changes and losses that take place in the silo, and the quality of the resulting silages as mesaured by chemical analysis, palatability and appearance.

\section{Literature Review}

The literature concerning the preparation of silage and the losses encountered in silage are reviewed by Woodward ${ }^{10}$ et al and LeClerc. ${ }^{6}$

May $^{7}$ erected the first silo in Puerto Rico at the Federal Experiment Station, Mayagüez. He secured good results using corn as ensilage but poor results with cane tops, Guinea grass and Para grass (Malojillo).

\section{Experimental}

Six concrete silos $71 / 2$ feet in diameter and 15 feet high, each having a capacity of 7 to 10 tons of fresh forage were used. A series of holes was made in the walls at random points at 4, 6 and 10 feet from the top. These holes were fitted with 2-inch capped pipes and were used for drawing samples for chemical analysis.

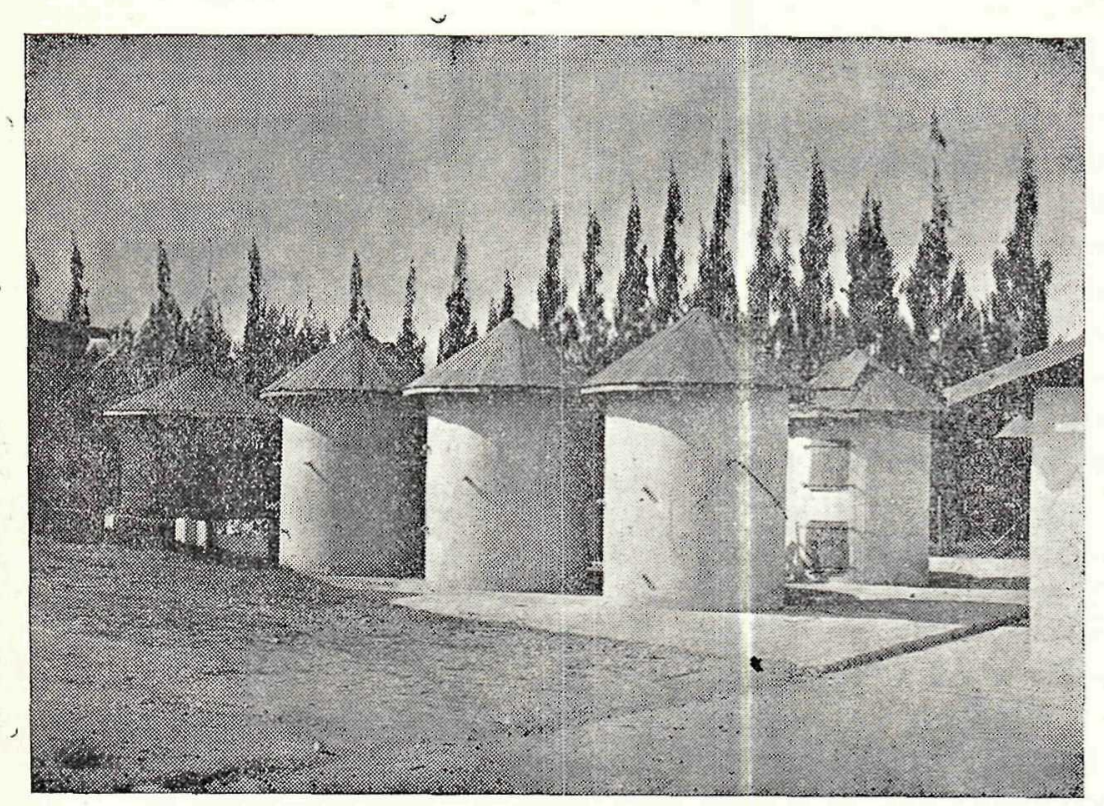

FIGURE 1.-Experimental Silos. Capacity 7 to 10 tons of green forage. 
Grasses were cut by use of a large-size Gehl cutter and were blown into the silos in the usual manner. At the same time, molasses was added by means of a pump attached to the silage cutter and its rate of addition regulated by means of a valve. Water was added by diluting the molasses, care being taken to insure the addition of the correct amount of molasses.

One man was used to distribute the cut grass and to trample it according to the specifications of each trial. The amount of fresh grass placed in each silo was estimated by averaging the weights of two ox carts of grass and multiplying the average by the number of carts used.

Para grass (Panicum barbinode), cane tops (Sacharum officinarum) and Merker grass (Penissetum purpureum var. Merkerie), were the forages used. Special emphasis was placed on the latter due to its increasing importance as a crop in Puerto Rico. Observations were made on the factors affecting the quality and quantity of the silage. Such factors were: length of chopped grass, moisture content of the grass, thoroughness of packing, and the maximum length of time which could elapse between partial fillings of the same silo.

Chemical analyses of the fresh grass (plus molasses when it was added) and of the silage were made from random samples of the material. The bag method was used for analysis in one trial. Moisture was determined by placing samples in an oven set at $70^{\circ} \mathrm{C}$ and equipped with a turbo blower. The $\mathrm{pH}$ was measured with a MacBeth $\mathrm{pH}$ meter. Other analyses were made according to the official methods of the Association of Official Agricultural Chemists. ${ }^{8}$ Calculations of the percentage of total nutrient losses were made by using the approximate amount of nutrients in the ingoing dry matter (total) and the amount of nutrients in the dry matter that was recovered as edible silage.

Factors considered in the evaluation of the quality of the silage were: $\mathrm{pH}$, odor, color and palatability. The latter was tested by a series of feeding trials in which silage and soilage of the same quality were used. All silos were opened thirty days after filling.

Nine silos were filled: six with Merker grass with ten per cent molasses, two with Para grass with five and ten per cent molasses, and one with cane tops to which no molasses was added. 
The forage was chopped $1 / 2$ inch long. This length of cut $1 / 2$ inch or shorter is recommended to insure packing. In silo No. 1 a man was used to level and trample the material at intervals of three ox carts chopped; in the rest of the silos the man was kept leveling and trampling constantly.

Water was added to all silages except to No. 9, at a rate of 3 to 5 per cent of the approximate weight of the forage. The amount varied according to the operator's judgment of dryness of the material.

\section{Results and Discussion}

In Table 1 the approximate total weight of material put into four of the experimental silos is shown.

TABLE No. 1

APPROXIMATE TOTAL WEIGHT OF MATERIAL PUT INTO FOUR OF THE EXPERIMENTAL SILOS

\begin{tabular}{|c|c|c|c|c|c|c|c|c|}
\hline Silage No. ${ }^{1}$ & $\begin{array}{l}\text { Number } \\
\text { of ox } \\
\text { carts of } \\
\text { grass } \\
\text { used }\end{array}$ & $\begin{array}{l}\text { Ave. } \\
\text { wgt. of } \\
\text { two ox } \\
\text { carts } \\
\text { lbs. }\end{array}$ & $\begin{array}{c}\text { (A ppro- } \\
\text { ximate) } \\
\text { total } \\
\text { weight } \\
\text { of forage }\end{array}$ & $\begin{array}{c}\text { Molasses } \\
\text { Per Cent }\end{array}$ & $\begin{array}{l}\text { Total } \\
\text { wgt. of } \\
\text { molasses }\end{array}$ & $\begin{array}{l}\text { Amount } \\
\text { of water } \\
\text { added } \\
\text { lbs. }\end{array}$ & $\begin{array}{c}\text { Water } \\
\text { added } \\
\text { by wgt. } \\
\text { of forage } \\
\text { Per Cent }\end{array}$ & $\begin{array}{c}\text { Total } \\
\text { wgt. of } \\
\text { material }\end{array}$ \\
\hline 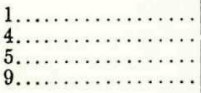 & $\begin{array}{l}12 \\
10 \\
10 \\
10\end{array}$ & $\begin{array}{l}1,488 \\
1,850 \\
1,187 \\
1,089\end{array}$ & $\begin{array}{l}17,856 \\
18,500 \\
11,870 \\
10,890\end{array}$ & $\begin{array}{l}10 \\
10 \\
10 \\
10\end{array}$ & $\begin{array}{l}1,785 \\
1,850 \\
1,137 \\
1,210\end{array}$ & $\begin{array}{l}799 \\
650 \\
543 \\
000\end{array}$ & $\begin{array}{l}4.50 \\
3.50 \\
4.50 \\
0.00\end{array}$ & $\begin{array}{l}20,440 \\
21,000 \\
13, \mathrm{t} 00 \\
12,100\end{array}$ \\
\hline
\end{tabular}

1 Merker grass used.

Due to the fact that the molasses pump was adjusted to spray at a rate of ten per cent when the chopper was fed continuosly, it appears that the total amount of forage calculated is approximately accurate. The fact that there was no bottom spoilage in any of the silos indicates that the amount of water was not excessive.

Chemical analyses of the ingoing grass and the resulting silage are presented in Table 2. 
TABI.E NO. 2

PROXIMATE ANALYSES OF THE GRASSES PLUS MOLASSES AND THE SILAGES

\begin{tabular}{|c|c|c|c|c|c|c|c|c|c|c|c|}
\hline \multirow{3}{*}{ No. of silo } & \multirow{3}{*}{ Grass } & \multirow{3}{*}{$\begin{array}{c}\text { Date } \\
\text { Ensiled }\end{array}$} & \multirow{3}{*}{$\begin{array}{l}\text { No. of } \\
\text { Samples }\end{array}$} & \multicolumn{8}{|c|}{ ANALYSES } \\
\hline & & & & Molasses & Moisture & $\begin{array}{l}\text { Dry } \\
\text { matter }\end{array}$ & Ash & $\begin{array}{l}\text { Crude } \\
\text { protein }\end{array}$ & $\begin{array}{l}\text { Ether } \\
\text { extract }\end{array}$ & Fiber & N. F. E.4 \\
\hline & & & & Per Cent & Per Cent & Per Cent & Per Cent & Per Cent & Per Cent & Per Cent & Per Cent \\
\hline $1 \ldots \ldots \ldots \ldots \ldots \ldots \ldots$ & $\begin{array}{l}\text { Merker.......... } \\
\text { Silage........... }\end{array}$ & $\begin{array}{r}12-6-46 \\
\cdots \cdots \cdots \cdots\end{array}$ & $\begin{array}{l}1 \\
2\end{array}$ & 10 & $\begin{array}{l}76.30 \\
76.70\end{array}$ & $\begin{array}{l}23.70 \\
23.30\end{array}$ & $\begin{array}{l}10.59 \\
11.36\end{array}$ & $\begin{array}{l}9.47 \\
9.53\end{array}$ & $\begin{array}{l}2.37 \\
3.52\end{array}$ & $\begin{array}{l}31.55 \\
32.22\end{array}$ & $\begin{array}{l}46.02 \\
43.39\end{array}$ \\
\hline $2 \ldots \ldots \ldots \cdots \cdots \cdots \cdots$, & $\begin{array}{l}\text { Merker........... } \\
\text { Silage............ }\end{array}$ & $\begin{array}{r}3-13-47 \\
\ldots \ldots+\cdots \cdots \\
\ldots \ldots \ldots\end{array}$ & $\begin{array}{l}2 \\
7\end{array}$ & 10 & $\begin{array}{l}76.25 \\
74.23\end{array}$ & $\begin{array}{l}23.70 \\
25.77\end{array}$ & $\begin{array}{l}6.51 \\
8.51\end{array}$ & $\begin{array}{l}5.13 \\
5.37\end{array}$ & $\begin{array}{l}2.25 \\
2.90\end{array}$ & $\begin{array}{l}35.54 \\
33.55\end{array}$ & $\begin{array}{l}50.58 \\
49.67\end{array}$ \\
\hline $3 \ldots \ldots \ldots$ & $\begin{array}{l}\text { Merker........... } \\
\text { Silage........... }\end{array}$ & $\begin{array}{r}3-18-47 \\
\ldots \ldots \ldots \cdots \cdots\end{array}$ & $\begin{array}{l}2 \\
7\end{array}$ & 10 & $\begin{array}{l}72.20 \\
72.76\end{array}$ & $\begin{array}{l}27.80 \\
27.24\end{array}$ & $\begin{array}{l}6.55 \\
8.30\end{array}$ & $\begin{array}{l}5.01 \\
5.21\end{array}$ & $\begin{array}{l}2.14 \\
2.70\end{array}$ & $\begin{array}{l}36.53 \\
33.15\end{array}$ & $\begin{array}{l}49.77 \\
50.64\end{array}$ \\
\hline $4 \ldots \ldots \ldots \ldots, \ldots, \ldots$ & $\begin{array}{l}\text { Merker........... } \\
\text { Silage............ }\end{array}$ & $\begin{array}{r}6-25-47 \\
\cdots \cdots+\cdots \cdots \\
\end{array}$ & $\begin{array}{r}11 \\
8\end{array}$ & 10 & $\begin{array}{l}82.40 \\
79.60\end{array}$ & $\begin{array}{l}17.60 \\
20.40\end{array}$ & $\begin{array}{l}11.25 \\
12.39\end{array}$ & $\begin{array}{l}5.88 \\
6.12 \\
\end{array}$ & $\begin{array}{l}2.13 \\
2.25\end{array}$ & $\begin{array}{l}33.56 \\
27.68 \\
\end{array}$ & $\begin{array}{l}47.18 \\
51.56\end{array}$ \\
\hline $5 \ldots \ldots \ldots \ldots \ldots \ldots$ & $\begin{array}{l}\text { Merker........... } \\
\text { Silage.......... }\end{array}$ & $\begin{array}{r}7-31-47 \\
\ldots+2-\cdots\end{array}$ & $\begin{array}{l}7 \\
8\end{array}$ & 10 & $\begin{array}{l}73.66 \\
72.72\end{array}$ & $\begin{array}{l}26.34 \\
28.00\end{array}$ & $\begin{array}{l}10.23 \\
13.55\end{array}$ & $\begin{array}{l}5.26 \\
6.28\end{array}$ & $\begin{array}{l}2.23 \\
2.41\end{array}$ & $\begin{array}{l}32.53 \\
28.08\end{array}$ & $\begin{array}{l}49.75 \\
49.88\end{array}$ \\
\hline $6 \ldots \ldots \ldots \ldots \ldots \ldots \ldots$ & $\begin{array}{l}\text { Cane tops......... } \\
\text { Silage............ }\end{array}$ & $\begin{array}{r}3-7-47^{1} \\
\ldots \ldots \cdots \cdots \\
\end{array}$ & $\begin{array}{l}2 \\
7 \\
\end{array}$ & & $\begin{array}{l}77.70 \\
76.86\end{array}$ & $\begin{array}{l}22.30 \\
23.14\end{array}$ & $\begin{array}{l}9.03 \\
8.93\end{array}$ & $\begin{array}{l}6.37 \\
6.75 \\
\end{array}$ & $\begin{array}{l}2.36 \\
1.74 \\
\end{array}$ & $\begin{array}{l}31.71 \\
34.76 \\
\end{array}$ & $\begin{array}{l}50.53 \\
47.82 \\
\end{array}$ \\
\hline $7 \ldots \ldots \ldots \ldots \ldots$ & $\begin{array}{l}\text { Para grass........ } \\
\text { Silage............ }\end{array}$ & $\begin{array}{r}11-26-47 \\
\ldots \ldots \cdots \cdots \cdots\end{array}$ & $\begin{array}{l}5 \\
6\end{array}$ & 10 & $\begin{array}{l}73.24 \\
71.89\end{array}$ & $\begin{array}{l}26.76 \\
28.11\end{array}$ & $\begin{array}{l}15.75 \\
18.28\end{array}$ & $\begin{array}{l}9.10 \\
8.54\end{array}$ & $\begin{array}{l}1.56 \\
1.27 \\
\end{array}$ & $\begin{array}{l}24.76 \\
25.37 \\
\end{array}$ & $\begin{array}{l}48.83 \\
46.54 \\
\end{array}$ \\
\hline $8 \ldots \ldots \ldots \ldots \ldots \ldots \ldots$ & $\begin{array}{l}\text { Para grass......... } \\
\text { Silage............ }\end{array}$ & $\begin{array}{r}11-28-47^{2} \\
\cdots \cdots \cdots \cdots \cdots \\
\end{array}$ & $\begin{array}{l}5 \\
6 \\
\end{array}$ & 5 & $\begin{array}{l}78.42 \\
79.07\end{array}$ & $\begin{array}{l}21.58 \\
20.93\end{array}$ & $\begin{array}{l}15.95 \\
16.42\end{array}$ & $\begin{array}{l}7.84 \\
6.64 \\
\end{array}$ & $\begin{array}{l}1.22 \\
1.15 \\
\end{array}$ & $\begin{array}{l}27.50 \\
30.40 \\
\end{array}$ & $\begin{array}{l}47.49 \\
45.39 \\
\end{array}$ \\
\hline $9 \ldots \ldots \ldots \ldots \ldots \ldots \ldots$ & $\begin{array}{l}\text { Merker........... } \\
\text { Silage............ }\end{array}$ & $\begin{array}{c}11-4-47^{3} \\
\cdots \cdots \cdots \\
\end{array}$ & $\begin{array}{l}5 \\
5\end{array}$ & 10 & $\begin{array}{l}69.78 \\
67.51\end{array}$ & $\begin{array}{l}30.22 \\
32.49\end{array}$ & $\begin{array}{l}10.40 \\
10.72\end{array}$ & $\begin{array}{l}7.30 \\
6.71 \\
\end{array}$ & $\begin{array}{l}1.62 \\
1.84 \\
\end{array}$ & $\begin{array}{l}34.19 \\
33.49 \\
\end{array}$ & $\begin{array}{l}46.49 \\
47.24\end{array}$ \\
\hline (9) $\ldots \ldots \ldots \ldots \ldots$ & $\begin{array}{l}\text { Bag sample } . . . . \\
\text { Silage........... }\end{array}$ & $\mid \cdots \ldots \ldots \ldots \ldots$ & $\begin{array}{l}1 \\
1\end{array}$ & 10 & $\begin{array}{l}69.10 \\
68.10\end{array}$ & $\begin{array}{l}30.90 \\
31.90\end{array}$ & $\begin{array}{l}10.83 \\
10.19\end{array}$ & $\begin{array}{l}7.06 \\
5.81\end{array}$ & $\begin{array}{l}1.71 \\
2.01\end{array}$ & $\begin{array}{l}34.58 \\
36.06\end{array}$ & $\begin{array}{l}45.72 \\
42.93\end{array}$ \\
\hline
\end{tabular}


Chemical composition of forage grasses has been shown to vary with the stage of maturity, soil conditions and climate. ${ }^{5}$ Young plants are characterized by their high protein content and high digestibility of their dry matter. The earlier the crop is harvested, the higher will be the protein and moisture content, but too early a harvest of any crop will reduce the tonnage. ${ }^{4}$ In general, the same rules may apply as regards time of cutting for silage as for soilage. The feeding value of silage will depend upon the feeding value of the fresh material, and the conditions under which it is ensiled. ${ }^{1}$

As all grasses are comparatively low in protein content, the soundest procedure would be to harvest the crop at a point where the maximum tonnage can be obtained with the least reduction in quality. In Puerto Rico, Merker grass is in good cutting condition just before bloom: 60 to 80 days old. Variations will arise due to farming practices and changes in weather conditions. Para grass is somewhat different; before bloom it is too short for cutting. The best time to cut is right after blooming, except for very fertile soils where good growth will permit earlier cutting. The time will vary between 50 to 70 days. For cane tops, the farmer has to wait until the sugar cane harvest.

The proximate total losses for Merker silage are presented in Table 3. 
TABLE NO. 3

APPROXIMATE LOSSES IN MERKER SILAGE PRESERVED WITH TEN PER CENT MOLASSES

\begin{tabular}{|c|c|c|c|c|c|c|c|c|c|}
\hline $\begin{array}{l}\text { Silage No. and } \\
\text { date ensiled }\end{array}$ & $\begin{array}{l}\text { Grass, } \\
\text { molasses } \\
\text { and water }\end{array}$ & $\underset{\text { Dry }}{\text { Drter }}$ & $\begin{array}{l}\text { Total } \\
\text { Dry } \\
\text { matter }\end{array}$ & $\begin{array}{c}\text { Intangible } \\
\text { loss }\end{array}$ & Loss & $\begin{array}{l}\text { Edible } \\
\text { silage }\end{array}$ & $\begin{array}{l}\text { Spoiled } \\
\text { silage }\end{array}$ & Loss & $\begin{array}{l}\text { Total } \\
\text { loss }\end{array}$ \\
\hline & Lbs. & Per Cent & Pounds & pounds & Per Cent & Pounds & & Per Cent & Per Cent \\
\hline 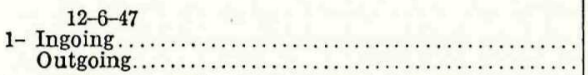 & $\begin{array}{l}20,440.00 \\
17,533.00\end{array}$ & $\begin{array}{l}23.70 \\
23.30\end{array}$ & $\begin{array}{l}4,844.28 \\
4,085.19\end{array}$ & 759.10 & $\begin{array}{r}15.67 \\
\ldots \ldots \ldots\end{array}$ & $16,213.00$ & $1,140.00$ & $6.50^{\circ}$ & 22.17 \\
\hline 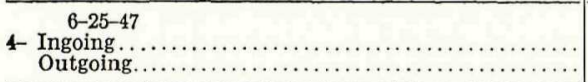 & $\begin{array}{l}21,000.00 \\
16,326.00\end{array}$ & $\begin{array}{l}17.60 \\
20.40\end{array}$ & $\begin{array}{l}3,696.00 \\
3,330.50\end{array}$ & 365.50 & 9.89 & $15,336.00$ & 990.00 & 6.06 & 15.95 \\
\hline 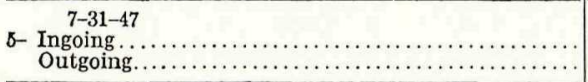 & $\begin{array}{l}13,600.00 \\
11,804.00\end{array}$ & $\begin{array}{l}26.34 \\
28.00\end{array}$ & $\begin{array}{l}3,582.24 \\
3,305.12\end{array}$ & $\begin{array}{c}277.12 \\
\ldots \ldots \ldots\end{array}$ & $\begin{array}{l}7.74 \\
\ldots \ldots . .\end{array}$ & $10,833.00$ & 971.00 & 8.23 & 15.97 \\
\hline 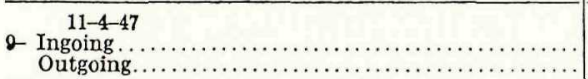 & $\begin{array}{l}12,100.00 \\
10,460.00\end{array}$ & $\begin{array}{l}30.22 \\
32.49\end{array}$ & $\begin{array}{l}3,656.62 \\
3,398.45\end{array}$ & $\begin{array}{r}258.17 \\
\ldots \ldots \ldots\end{array}$ & 7.06 & $9,620.00$ & 840.00 & 8.03 & 15.09 \\
\hline $\begin{array}{c}\text { Bag Sample } 11-4-47 \\
\text { Ingoing } \ldots \ldots \ldots \ldots \ldots \ldots \ldots \ldots \ldots \ldots \ldots \ldots \ldots \ldots \ldots \ldots \ldots \ldots \ldots \ldots \ldots \ldots \ldots \ldots \ldots \ldots \ldots \ldots \ldots \ldots\end{array}$ & $\begin{array}{l}471.50^{1} \\
442.10\end{array}$ & $\begin{array}{l}30.90 \\
31.90\end{array}$ & $\begin{array}{l}145.70^{1} \\
141.03\end{array}$ & 4.671 & 3.20 & & & & $\cdots$ \\
\hline
\end{tabular}

1 Weight in grams. 
The importance of good packing was indicated by the results of total losses in silage No. 1 as compared with the other three. The larger losses in silo No. 1 were probably due to the fact that leveling and tramping were done at intervals instead of having a man constantly in the silo, as in the other three; packing was not as good as in the others.

Table 4 presents a summary of total nutrient losses compared to the losses reported by other workers in the field.

TABLE NO. 4

SUMMARY OF NUTRIENT LOSSES IN PERCENTAGE LOSS OR GAIN

\begin{tabular}{|c|c|c|c|c|c|c|}
\hline & $\begin{array}{c}\text { Dry } \\
\text { matter }\end{array}$ & Ash & $\begin{array}{l}\text { Crude } \\
\text { protein }\end{array}$ & $\begin{array}{l}\text { Ether } \\
\text { extract }\end{array}$ & Fiber & $\begin{array}{l}\text { Nitrogen } \\
\text { free extract }\end{array}$ \\
\hline $\begin{array}{l}\text { Silo No. } 1 \ldots \ldots \ldots \ldots \ldots \ldots \\
\text { Silo No. } 4 \ldots \ldots \ldots \ldots \ldots \ldots \ldots \\
\text { Silo No. } 5 \ldots \ldots \ldots \ldots \ldots \ldots \\
\text { Silo No. } 9 \ldots \ldots \ldots \ldots \ldots \\
\text { Bag sample }(9) \ldots \ldots \ldots \ldots\end{array}$ & $\begin{array}{r}-22.02 \\
-15.40 \\
-17.50 \\
-14.52 \\
-3.30\end{array}$ & $\begin{array}{r}-16.34 \\
-6.82 \\
+7.66 \\
-14.52 \\
-8.94\end{array}$ & $\begin{array}{l}-21.56 \\
-11.85 \\
-1.51 \\
-21.43 \\
-20.40\end{array}$ & $\begin{array}{l}-15.83 \\
-10.57 \\
-10.84 \\
-\quad 2.92 \\
+\quad 13.65\end{array}$ & $\begin{array}{r}-20.36 \\
-23.17 \\
-28.79 \\
-16.27 \\
+\quad 8.98\end{array}$ & $\begin{array}{r}-26.47 \\
-13.86 \\
-17.29 \\
-13.14 \\
-9.12\end{array}$ \\
\hline $\begin{array}{l}\text { Le Clere (6) citing Henry } \\
\text { and Wall and Woodman } \\
\text { and Amos }{ }^{1} \ldots \ldots \ldots \ldots \ldots \ldots \\
\text { Ragsdal and Turner (9)... }\end{array}$ & $\begin{array}{r}-5.8 \text { to } \\
-18.1 \\
-2.1 \text { to } \\
-18.1\end{array}$ & $\begin{array}{l}+3.1 \\
-6.8 \\
-11.7 \\
-15.7\end{array}$ & $\begin{array}{l}+2.0 \text { to } \\
-12.2 \\
+5.1 \text { to } \\
-38.4\end{array}$ & $\begin{array}{l}+59.0 \text { to } \\
-122.0 \\
+49.4 \\
-20.3\end{array}$ to & $\begin{array}{l}+0.90 \text { to } \\
-11.80 \\
+6.70 \text { to } \\
-14.6\end{array}$ & $\begin{array}{l}-16.20 \text { to } \\
-24.90 \\
-5.8 \\
-22.5\end{array}$ to \\
\hline
\end{tabular}

1 Using bag samples.

Results obtained on total losses and nutrient losses are within the range of the findings of other investigators $2,3,6,9$. There is a wide variation in the percentage of losses or gains. It is apparent that appreciable quantities of nutrients are lost and that the losses silage undergoes depend upon the size of the silo, amount of silage and on the methods and techniques used. 
The results obtained on $\mathrm{pH}$ values in three of the experimental silos are presented in tables 5 and 6 .

TABLE NO. 5

pH VALUES AT DIFFERENT INTERVALS AND AT DIFFERENT LEVELS. MERKER GRASS, TEN PER CENT MOLASSES

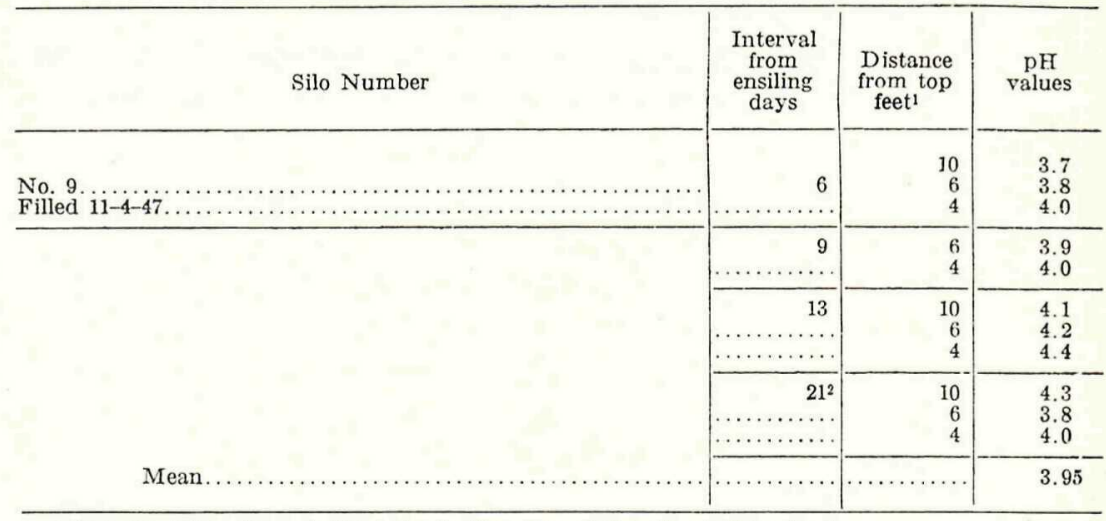

1 Samples taken through the holes in the sides of the silo at those levels.

2 No more samples were taken from there on due to mold contamination around sampling holes.

TABLE NO. 6

PH VALUES AT DIFFERENT INTERVALS AND AT DIFFERENT LEVELS MERKER GRASS TEN PER CENT MOLASSES

\begin{tabular}{|c|c|c|c|}
\hline Silo Number & $\begin{array}{l}\text { Interval } \\
\text { from } \\
\text { ensiling } \\
\text { days }\end{array}$ & $\begin{array}{l}\text { Distance } \\
\text { from top } \\
\text { feet }\end{array}$ & $\underset{\text { values }}{\mathrm{pH}}$ \\
\hline 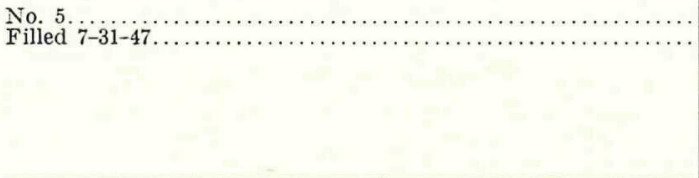 & $\begin{array}{l}35 \\
37 \\
39 \\
43 \\
46 \\
50 \\
53 \\
57\end{array}$ & $\begin{array}{r}2.0 \\
3.0 \\
5.0 \\
6.0 \\
7.0 \\
9.0 \\
10.0 \\
13.5\end{array}$ & $\begin{array}{l}4.1 \\
4.1 \\
4.2 \\
4.0 \\
4.3 \\
4.0 \\
3.8 \\
4.1\end{array}$ \\
\hline 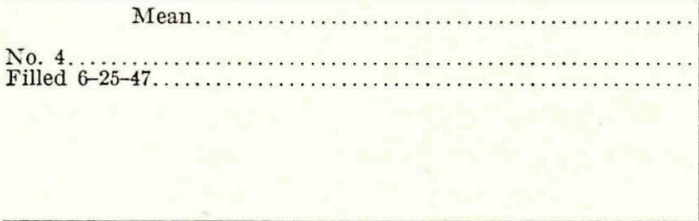 & 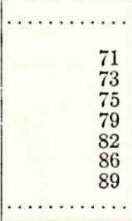 & $\begin{array}{r} \\
2.0 \\
3.0 \\
5.0 \\
6.0 \\
7.0 \\
9.0 \\
10.0 \\
13.5\end{array}$ & $\begin{array}{l}4.05 \\
4.3 \\
4.3 \\
4.0 \\
4.1 \\
4.6 \\
3.8 \\
3.6 \\
4.2\end{array}$ \\
\hline 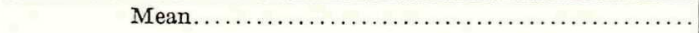 & $\ldots \ldots \ldots \ldots$ & $\ldots \ldots \ldots \ldots$ & 4.01 \\
\hline
\end{tabular}

1 Samples obtained as the silage was taken out for use.

The $\mathrm{pH}$ values obtained indicate that Merker silage was preserved in excellent condition. These values are in agreement with the findings of other investigators which give the same range of $\mathrm{pH}$ values for good silage ${ }^{3,6,10}$. 
Due to the natural characteristics of Merker grass, which has light leaves and hard bulky stems; Para grass, which has light and hollow stems; and cane tops, which are bulky and nearly always quite dry; chopping to $1 / 2$ inch or less, the addition of some water, especially toward the top of the silo, and continuous tramping are essential factors to be considered when ensiling in order to get good packing and prevent excessive losses (especially top spoilage and spoilage toward the walls of the silo).

Wilting is not advisable for the reasons pointed out above; the material will become too light to attain good packing, even with tramping. In addition, the hot tropical sun will destroy a large portion of the carotene and part of the protein during the wilting period. It is true that too much moisture will cause some spoilage in the bottom of the silo, but too little moisture is much more serious than too much.

Merker grass plus ten per cent molasses produced a very palatable "green, fruity" " silage with a pleasant molasses odor. Para grass with five or ten per cent molasses produced a "sweet, dark-brown" " silage of a much lower quality than Merker silage, as regards color, odor and palatability. Of the two Para grass silages, the ten-per-cent molasses silage was more palatable and had a more pleasing odor than the five-per-cent silage, as indicated by the fact that the cows consumed the former more readily. Para grass has the disadvantage that dirt is nearly always found in it due to its habit of growth: close to the ground and in swampy places. This, without doubt, affects quality adversely.

Cane tops were ensiled satisfactorily without molasses. They produced a coarse silage, lower in quality than Merker. Cattle ate it and because cane tops are harvested during the dry season, the silage makes a good substitute for Merker or Para grass soilage and other pasture crops which are affected by drought. A large quantity of sugar cane is grown in the Island and cane tops are very easy to get during the harvest season that lasts from three to five months.

Para grass and cane tops were ensiled satisfactorily, contrary to the findings of $\mathrm{May}^{7}$ who used a very dry material adding no water. Very poor packing was probably attained.

Molasses has been considered one of the best, if not the best, preservative for silage ${ }^{1},{ }^{4},{ }^{6},{ }^{10}$. In Puerto Rico, where sugar 
cane is the main cash crop, molasses is cheap, a little less than two cents a pound, and easy to get. Many of the dairymen are also sugar cane growers and have a share of the molasses produced from their cane. They are, therefore, in a very favorable position to face the scarcity of pasture and soiling crops during the dry season by erecting silos of adequate size for their herds and preserving grasses with molasses.

Observations tend to indicate that, probably due to the warmer temperatures in Puerto Rico, the interval to resume filling the silo, after it is partly filled, should not exceed more than 24 hours because a very dense layer of molds will grow very rapidly on the uncovered portion. This moldy layer has to be removed before resuming the filling operation, consuming extra labor and increasing the loss of material.

\section{Summary and Conclusions}

Merker grass, Para grass and cane top silages were made satisfactorily using experimental silos $7.5^{\prime} \times 15^{\prime}$. The commonly recommended techniques, except wilting, can be followed in Puerto Rico. Observations tend to indicate that the forage should be put into the silo within a few hours after cutting. Due to the natural characteristics of the native-grown grasses and of the excessively hot sun, wilting it not advisable: the material becomes too light to attain good packing and there is a probable reduction in the nutritive value.

Unless very heavy weights are put on top of the ensiled material (this is troublesome and costly in tower silos), water must be added to insure good packing especially toward the top of the silo. Experience will help to determine the amount of water to be added.

More detailed studies on total losses, nutrient losses and $\mathrm{pH}$ values were made with Merker silage. The results obtained were within the range reported by investigators in the United States.

Further observations tend to indicate too, that intervals between fillings should not exceed more than 24 hours to avoid excessive losses due to moldy silage. The tropical temperature seems to favor the rapid growth of molds.

With respect to odor, color, palatability and $\mathrm{pH}$ values, very good silage was obtained from Merker grass. Good cane tops 
and Para grass silages were obtained too, but not of the same quality as Merker silage.

Molasses can be used as a preservative up to ten per cent. It increases palatability and nutritive value of the silage.

Results obtained with Merker grass silage probably apply to the other forage grasses in the Island, taking into consideration the results obtained in the present work as compared to the results obtained by others with grass and legume silages.

\section{Acknowledgement}

The authors are greatly indebted to Dr. W. W. Green for his invaluable suggestions and for the revision of the manuscript.

\section{REFERENCES}

1. Allen, N. N. and J. B. Fitch. Hay erop silage. Minnesota Agric. Expt. Sta. Bul. 360. 1942.

2. Archibold, J. B. and C. I. Gunness. Seepage losses from silo. Jour. Dairy Sci. 28:321, 1945.

3. Autrey, K. M., C. B. Knodt, and D. S. Williams. Grass and legumes silage studies using 2-quart glass jars as miniature silos. Jour. Dairy Sci. 30:775, 1947.

4. Dickey, Jr. R. B., Peterson, V. S., Olmstead, R. H., and Bechdel, S. I. Suggestions on making legume and grass silage. Mimeo. Rep. Penn State College, Agric. Ext. Serv. Second Rev. 1941.

5. Huffman, B. A. Roughage quality and quantity in dairy ration, a review. Jour. Dairy Sei. 22:889. 1939.

6. LeClerk, J. A. Losses in making hay and silage U.S.D.A. Yearbook of Agriculture pp. 992.1939.

7. May, D. W. Dairying in Puerto Rico. P. R. Agric. Expt. Sta. Mayagüez, P. R. Bul. 29: p. 12-13. 1922.

8. Official and tentative methods of analysis of the Association of Official Agricultural Chemists, Sixth Ed. p. 404-409. 1945.

9. Rogsdale, A. C. and Turner, C. W. Silage investigations. Loss of nutrients in the silo and during field curing of corn. Mo. Agric. Expt. Sta. Res. Bul. 60. 1924.

10. Woodward, T. E., Hasterman, W. H., Cardon R. V., and McComas, E. W. The nutritive value of harvested forages. U.S.D.A. Yearbook of Agriculture, p. 956. 1939. 